Mirjana Petković1, Dubravka Djedović-Nègre ${ }^{2}$, Jelena Lukić ${ }^{3}$ ${ }^{1}$ University of Belgrade, Faculty of Economics, Serbia ${ }^{2}$ European Investment Bank', Luxembourg ${ }^{3}$ Parallel d.o.o., Belgrade

\title{
Public-Private Partnerships: Interorganizational Design as Key Success Factor
}

\author{
UDC: 658.114 .2 \\ 005.53:005.591.45 \\ DOI: 10.7595/management.fon.2015.0028
}

\begin{abstract}
Public-Private Partnership (PPP), as a current topic in theory and practice, has mostly been treated from the perspective of legislation and recognized by classical macroeconomic paradigm. The aim of this paper is to open a new aspect of dealing with this topic, both organizational and managerial. The paper underlines the importance of organizational design in a PPP, because experience has shown that without strong organization, coordination, defined rules and principles, there is no successful outcome and initiatives amount to a failed attempt. This is why interorganizational relations require well defined organizational architecture where it is clearly determined who, what, how and by when needs to deliver. In a PPP, this is achieved through a contractual framework and the creation of a special purpose company (SPC). The paper also affirms a new managerial position - PPP Manager - that apart from the general managerial skills and knowledge needs to be specialised in managing PPPs.
\end{abstract}

Keywords: public private partnership, interorganizational design, coordination, formalization, PPP manager

\section{Introduction}

Public-Private Partnerships (PPPs) are a current topic in academic, professional and political circles of the modern era, in both developed and less developed countries. For Serbia, this issue is of particular importance, since it is a low income country that has no potential to independently implement large and expensive projects that are a precondition for attracting investors, increasing employment, providing better quality of life, as well as social and political stability. In order to be implemented, the road infrastructure, railways, power plants, municipal landfill sites and many other expensive projects often have to be supported by various forms of partnerships.

This model of implementation of large, complex and expensive ventures is not a novelty. From ancient Greece and Rome and Byzantium, the great monarchies and republics, people have sought to develop and improve infrastructure as a necessary precondition for the development of all economic activities. In parallel with the development of technology, new needs of society emerged, the existing infrastructure was becoming outdated, and the new one was increasingly expensive to invest into and maintain. Since the mid-twentieth century, and especially since the beginning of the 90 s onwards, there is a need for alternative ways of financing large and expensive projects in which the public sector is traditionally interested, perceiving them as a possibility to improve economic growth and employment at the national level. However, as countries were increasingly faced with limited budgetary resources for financing public needs, the establishment of interorganizational relations with the private sector seemed an all the more attractive strategy. Namely, establishing relations with employers, who carry out their business in different sectors of the economy and who have excess capital and interest to invest in large and expensive infrastructure projects, is seen as a life-saving solution for many countries which have become aware that PPP is the only way to renew their infrastructure and to build new facilities of public importance. 
This strategy has become so widespread in practice it can even be said that the PPP has led to a real revolution in relation to traditional financing of public services in much of the world. However, regardless of this, it is symptomatic that there is still a lack of scientifically based analysis and descriptions of PPPs from which it could be seen how issues of organization and management are regulated, as well as which organizational model is a good support for the partnership. Even fewer are the analyses of the effects of the partnership. In this regard, attention in this paper is particularly paid to the matter of choosing the shape of the organizational forms of partnership, management models and side effects of interorganizational relations established between the partners. The reason for this is an undoubted fact that in any business, organizational design is a key success factor. In this sense, the objective of this study is to analyse the role and significance of interorganizational design that should be a support for the accomplishment of the established partnership goals. The initial research questions are: (1) can interorganizational relations in a PPP be supported by the traditional forms of organizational design, which are known as hierarchical structures? (2) does PPP require a new design with a looser structure and more flexibility? (3) if PPP is a loose structure, how to ensure coordination and authority? and (4) does managing a PPP involve specific managerial skills and abilities, and which ones? First, we will present the key features of the basic elements of a PPP, as well as the motives for their establishment from the perspective of the public and private partners. Then we will highlight the importance and role of interorganizational design that needs to support and assist the realization of PPP objectives, with special reference to the specifics of coordination mechanisms, the degree of formalisation of the participants' behaviour, authority holders and their competences.

\section{Public-private partnership: key characteristics and principles}

Public-private partnership is characterized by long-term cooperative and legal relations established between the public and private sectors with a view to plan, design, finance, build and manage the projects that belong to the domain of public services. A key feature of PPP is cooperation, as the ability of people and organizations from the private and public sectors to work together and combine what is best from these two sectors (Davey, 2010) and achieve multiple benefits by joint actions (Holland, 1984).

Through long-term cooperative relations between public and private organizations, PPP has a number of advantages over the traditional reliance on the public sector $(\mathrm{Ho}, 2006)$ that realized it could no longer cope on its own in meeting the growing needs of modern society (Handy, 1990). These advantages are reflected through (Osborne, 2000): 1) synergy effect, because the sum of the joint work of partners is higher than the sum of the results that the partners would independently achieve; 2) shared leadership, in which partners alternate in the role of leadership in individual phases of the project, depending on the required knowledge, skills, experience and competences they possess; 3 ) creating value for the community.

In this sense, one can speak about the characteristics of a PPP, which have become eventually manifested as distinctive features of PPPs (see Table 1).

Table 1: Key characteristics of PPPs

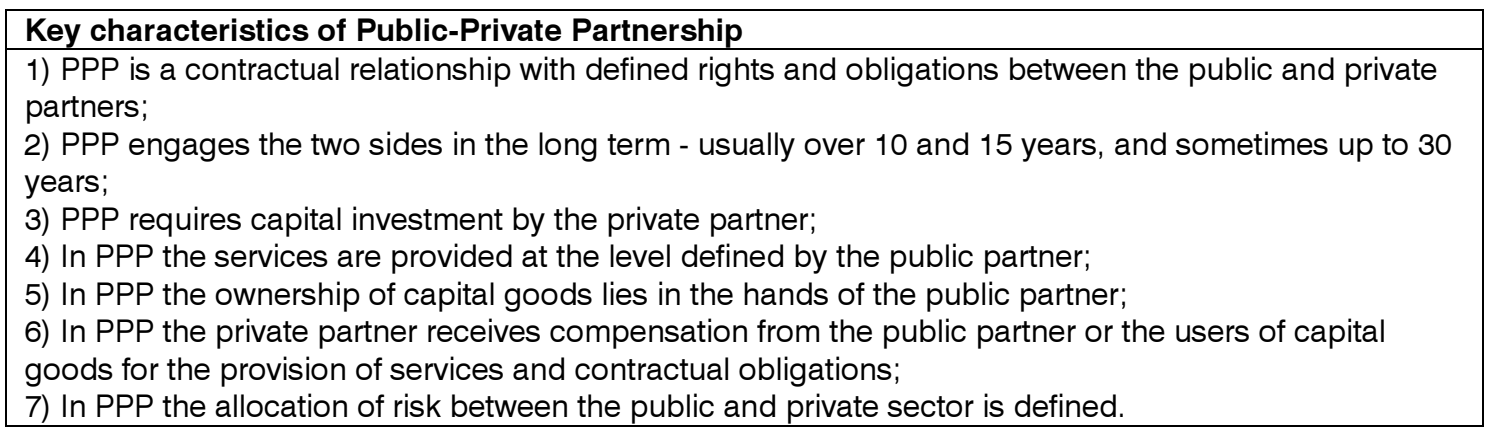

Source: Adapted from Yescombe, E. R. (2007). Public-Private Partnership, Principles of Policy \& Finance. London: Yescombe Consulting Ltd. 
Through the so-called traditional procurement of public services and infrastructure, the public sector has a role of the contractor and financier, where the infrastructure is built separately from its management and maintenance. State ministries and public authorities announce a call for the construction of infrastructure and pay the compensation for the construction from their own budgetary resources. After the completion of the project, public service and maintenance are provided by the public sector through its employees or through contracts with specialized operators. PPP brings all these activities together, so that the public sector appoints one contractor through a public call that, associated with several specialized partners in specific areas - finances, constructs - maintains and organises the provision of services in the long term based on the contractual relationship with the public partner. One of the driving goals of PPP is to utilize the management expertise, business practices (rules and procedures), financial capability and efficient organization of the private sector with the aim of providing public services better and more efficiently than the public sector (Yang, Hou, \& Wang, 2013).

However, it is important to emphasize that the PPPs go a step further than the contractual obligations of public and private partners. A public authority or the competent ministry is not just a client to a private entity, but also a partner that bears a part of the project risk. In each of the project stages, the public partner has different roles. The public authority performs an analysis of public needs, adopts national development and sector strategies by which it identifies investment needs and announces public tenders, prepare a draft of concession or PPP agreements. In addition, the public partner defines the performances and standards the private partner is to achieve, oversees the implementation of tasks and monitors the availability of public services in line with national and project objectives. On the other hand, the private partner undertakes to build, fund, manage capital goods and maintain them by such standards as defined by the public partner in a PPP agreement. The private partner establishes a special purpose vehicle or company (SPV/SPC), which may be its individual ownership or a shareholding of different companies selected through a public tender to implement PPP projects.

\section{Interorganizational design as a public private partnership's success factor}

Viewed through history, certain forms of organization have been conditioned by economic, technological and social circumstances (Miles \& Snow, 1992). The PPP is undoubtedly the kind of strategy based on interorganizational relationships, which consequently implies finding an appropriate organization design to support PPP objectives. Classic Chandler's rule that "structure follows strategy" (Chandler, 1962), here reflects that the PPP as a business strategy should involve an appropriate organization. This rule implies that the strategy of PPP requires layered organizational adjustments of partners. Unfortunately, only the most advanced managers pay organizational design appropriate attention, because they have learned through experience that without good organization even the best projects come down to mere attempts. Up to today, studies of PPPs have been focused on the benefits achieved by pooling: reduced costs, increased productivity, synergistic effect, risk-sharing between the partners, a shorter time needed for the project realization and the like (Jamali, 2004; Roseneau, 1999; Zhang, 2005). Mostly, the focus has been on direct economic effects that can be quantified, while at the same time it is ignored that behind this stands a particular organization and management. In addition, the importance of indirect effects that are manifested much later, such as the adopted work technologies, new knowledge, standards, leadership, culture, human resources policies, and other so-called invisible dimensions of organization, are unjustly neglected. Organizational components of PPP functioning are placed in the background, and many PPPs fail precisely because they are not well managed, because they do not have an appropriate organization as support, nor clearly enough defined coordination mechanisms of project participants. In the process of choosing a model of organization and creation of its components, the specificity of PPP should be respected (see Table 1), meaning that organizational solutions from other companies should not be copied, as managers and consultants often do.

Organizational design is by nature an unstructured problem in which it is necessary to reconcile the interests of different stakeholders (Grandori, 2002), which is particularly evident in the PPP where there is a large number of participants from both the public and private sectors that have different interests and organizational characteristics. Public organizations differ from the private ones in many features (Van der Wal, De Graaf\&Lasthuizen, 2008). First of all, public organizations have higher levels of bureaucracy and formalisation, their operation depends on a number of other organizations, operational efficiency is lower, while managers have not only a much lower degree of freedom in making decisions, but most often lack managerial 
skills and abilities (Rainey \& Bozeman, 2000). Therefore, it is more difficult for public organizations to change their usual way of functioning and switch from the hierarchy and isolation to cooperation and openness by entering into a PPP and changing the key elements of the established organizational design: strategy, structure, business processes, human resource policy, reward system (Kates \& Galbraith, 2007).

Interorganizational design should enable all partners in the PPP to accomplish their objectives, but also the objectives for which they entered the interorganizational relationship (Osborn \&Baughn, 1990), because they bring in their specific resources - space, technology, people, knowledge, and access to new markets (Delgado, Porter, \& Scott, 2010). In the internal organizational design there has to be a repositioning of employees and changes in their roles, and then an external organizational design is created, from which arise various manifestation forms of interorganizational design, usually in the form of:interorganizational networks (Miles \& Snow, 1992), interorganizational teams (Stock, 2006), meta (informal) organizations (Gulati, Phanish, \&Tushman, 2012), and organizations oriented to the actors (Fjeldstad et al., 2012). These organizational forms differ from the traditional structure models in their ability to adapt to the conditions in which partnership projects are realized (Jaško, Jaško, \&Čudanov, 2010). In this respect, their efficiency is enhanced due to the fact that by decentralising the decision ensuring that they clearly address responsibility and authority. Decisions are made by those who have the greatest knowledge and have the best information, which in turn leads to greater self-reliance of individuals and teams (Petković\&Lazarević, 2012; Mijatović, 2014; Petković, Aleksić-Mirić, \&Čudanov, 2014). In interorganizational relationships such as PPP, the research focus should be shifted from individual organizations to a wider and larger ecosystem such as partner networks (Figure 1) in which individual organizations become only nodes that have the same goal - successful implementation of the project (O'Callaghan, 2005).

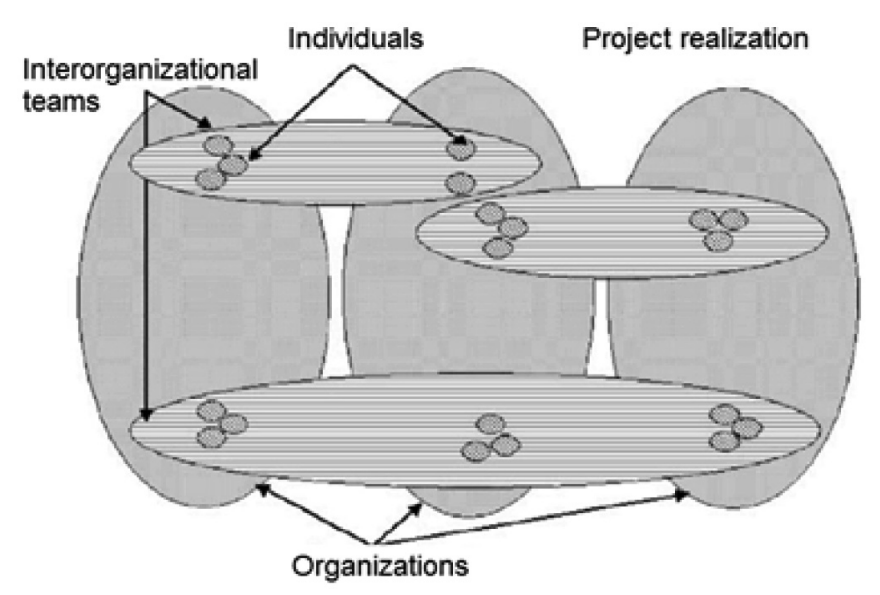

Figure 1: Interorganizational design

Source: Adapted fromHiggins, K. L., \&Maciariello, J. A. (2004). Leading complex Collaboration in Network Organizations: A Multidisciplinary Approach. In M. Beyerlein, D. Johnson \& S. Beyerlein (Eds.), Building the Capabilities for Working across Boundaries, Elsevier, Vol. 10, pp. 203-241.

Interorgranizational design, as illustrated in Figure 1, includes the establishment of cooperation between a large number of participants that can be organizations, teams or individuals (Alvesson \& Thompson, 2005; Zammuto et al., 2007). In a PPP, this is achieved through the establishment of a special purpose vehicle or company (SPV/ SPC) whose aim is to gather, often virtually, all the PPP participants.

The primary task of an SPC is the realization / implementation of the project which is the subject of the PPP or the concession agreement. The SPC is the main hub of the realization of a PPP project through which most of the decisions are made, in accordance with the contractual provisions (Figure 2). 


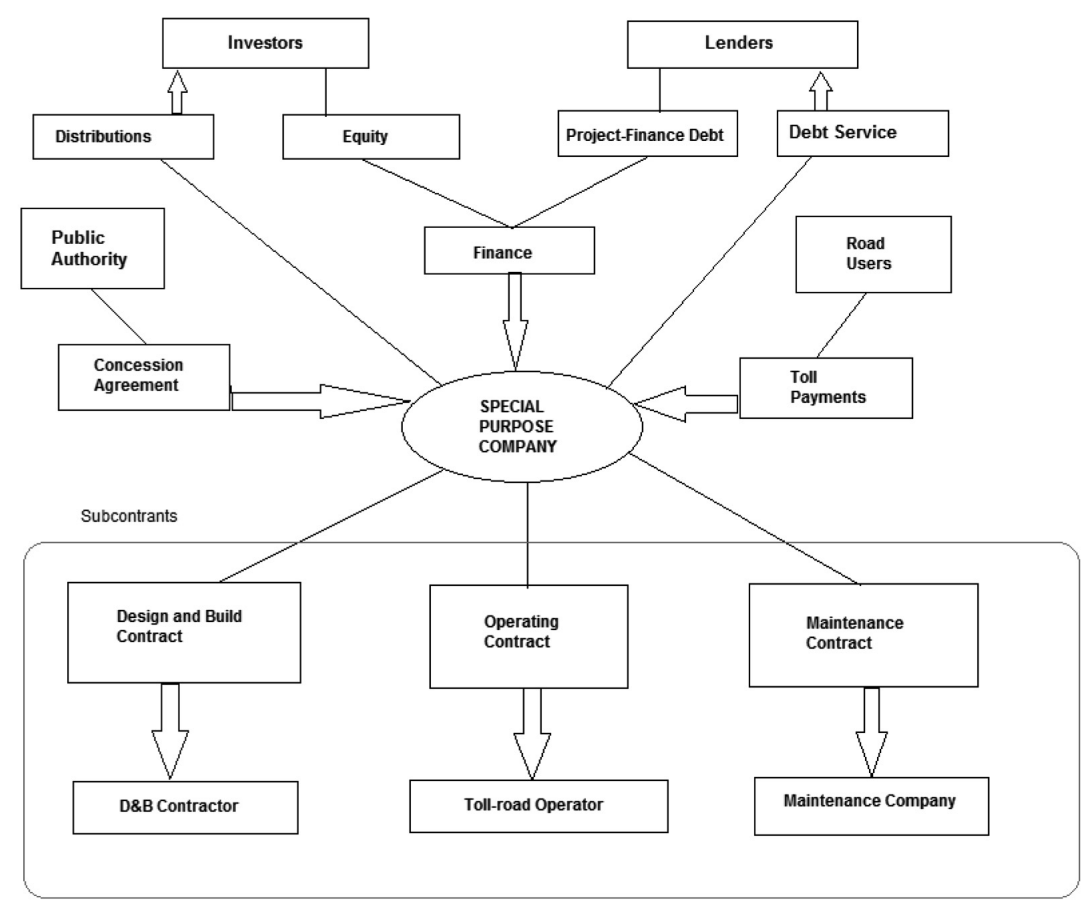

Figure 2: PPP model example for a road concession

Source: Adapted from Yescombe, E. R. (2007). Public-Private Partnership, Principles of Policy \& Finance. London: Yescombe Consulting Ltd., p. 9

From the previous review, it is clear that the traditional organization in its original form cannot be applied to the PPP as its basic model of organization, because it does not provide the necessary flexibility and dynamism. However, it cannot be a priori rejected either, because each organization, including the PPP needs rules and procedures, discipline, responsibility and authority. Compared to traditional forms of cooperation such as alliances, PPPs differ considerably because PPP participants do not have the same organizational structure. One partner is from the public sector, while the other is from the private sector. Also, the results of a PPP are always related to value creation for third parties, or a society as a whole (Zhang \&Jia, 2009).

It follows that the organization of the PPP through a special purpose company (SPC), which is established for the purposes of implementing the PPP project, must be some sort of a hybrid organization (Snow et al., 1993). As a rule, these are matrix structures based on different types of teams (expert, working, homogeneous, heterogeneous, virtual, and global). Matrix structures provide necessary conditions for the successful functioning of the PPP. In the first place, it is the transfer of knowledge and learning in teams, and then the necessary coordination and integration of the undertaken activities. In addition, matrix structures are suitable for the development of a team leadership, or a co-leadership. On the other hand, the matrix structures have disadvantages in terms that they are not suitable for the stability of organization and routine behaviour, which the employees in the public sector are inclined to, so that can create an atmosphere of instability, uncertainty and insecurity, which does support the increase in labour productivity. Therefore, it is necessary to prepare the human resources for teamwork in advance, especially due to the presence of employees from different departments of the public partner, who may be good individual experts, but not used to teamwork. Therefore, it is necessary to organize trainings for the PPP participants, in order to prepare them to carry out project tasks successfully.

Interorganizational design that supports the PPP, in addition to the classic issues of micro organization of the work process, also involves the behavioural dimension of the PPP, where trust among partners is of crucial importance. There are few works on this subject, and yet in the few professional publications it can be seen that this dimension is greatly highlighted, namely, that without trust there is virtually no partnership. The partnership is entered into with trusted partners (Zhang \& Jia, 2009). When establishing interorganizational relations, the concept of trust refers to the trust that exists among all participants (Zhang \&Jia, 2009). Trust in a partnership is an expectation that the other party will fulfil its obligations in a previously defined manner (Zaheer, McEvily, \&Perrone, 1998). In PPP initiatives, it has been proven that the key elements of trust are (Smyth \&Edkins, 2007): expectations from the other party, belief that the other party will behave in an agreed manner, hope that the other party will behave as defined, and the reliability of partners (their confidence). 


\section{Coordination mechanisms in PPP}

The presence of a large number of participants in a PPP increases the need for clearly defined coordination mechanisms, because poor coordination between public and private partners, as well as poor coordination within each of these groups would inevitably lead to problems in the project implementation, exceeding deadlines and increased costs. Key participants that commonly occur on the part of the public partners are technical, financial and legal advisors, while on the side of the private partners there are, in addition, architects, constructors, and operators (Robinson, 2010). Apart from them, a number of other participants play a role in a PPP, such as banks and creditors, insurance companies, independent auditors, subcontractors, various other advisers, etc.

Coordination is a mechanism for integrating the efforts of individual parts of the organization towards a single goal. Traditional mechanisms of coordination (Mintzberg, 1980) - direct supervision, mutual adjustment, standardization of inputs, outputs, knowledge and skills are being increasingly replaced by the so-called soft organizational instruments such as organizational culture and leadership (Jones, 2012; Burton \&Obel, 2004). In addition, with the influence of modern technology and the appearance of complex forms of labour, there has been the emergence of entirely new forms of coordination mechanisms such as informal groups, electronic communication, teams, integrating managerial positions (coordinators), dual (matrix) reporting forms (Galbraith, 2014).

A key coordination mechanism of a PPP is a concession or PPP agreement, which defines the rights, obligations and responsibilities of all participants. However, in practice, the agreement is usually not sufficient and it is not the only guarantee of success because partners enter into conflicts, breach of contract and disputes. A high level of integration in the PPP can be achieved by soft organizational instruments, such as organizational culture, leadership, trust, and communication. For this reason, it is of great importance for all the participants in the PPP that there are managers (coordinators) who will play an integrative role and will be engaged full-time in the distribution and control of the tasks performed by all participants of the PPP that make a team with a common goal. As this is a partnership between public and private partners, both sides have to be represented in the project leadership. This is why the concept of co-leadership is very important. Management of the PPP is the responsibility of the PPP managers, both on the public and the private sector sides.

This position is critical to the success of a PPP. Therefore, it cannot be occupied by managers without required references. All stakeholders in the partnership should have their PPP managers with specific knowledge and experience. In this respect, the position of a PPP manager involves certain responsibilities, such as resource allocation, cooperation between different project participants, coordination of the project participants - public partners, private companies (the so-called sponsors), creditors, consultants and advisers, monitoring project implementation, reporting on the stages of implementation, etc. In addition, managers' tasks are focused on the co-ordination of roles and responsibilities of individual participants in the project. Consequently, the position of a PPP manager requires a multidiscipline (possession of professional knowledge in the field of the project but also the so-called soft business skills) and experience in the field of the project ${ }^{2}$.

Table 2: Key tasks and responsibilities of a PPP manager

\begin{tabular}{|l|}
\hline Tasks and Responsibilities \\
\hline Managing the PPP implementation \\
\hline Consulting all line managers relevant to different project stages \\
\hline Forming and managing project teams \\
\hline Monitoring the flow of spent and available resources and reporting to relevant entities \\
\hline $\begin{array}{l}\text { Managing information systems necessary for the process of planning and implementing the further } \\
\text { course of the project }\end{array}$ \\
\hline Monitoring the results of individual project stages \\
\hline Solving conflicts, motivating the participants \\
\hline
\end{tabular}

Source: Authors

${ }^{2}$ For more information look in: Innovative Program Delivery (2012) Establishing a Public-Private Partnership Program: An example, P3 Toolkit. 
A PPP manger needs to have the characteristics of the so-called T professional, who has in-depth knowledge in one field (vertical line of the letter $\mathrm{T}$ ) and at the same time possesses knowledge and skills in other fields and disciplines (horizontal line of the letter T), which makes such a professional equipped to cooperate with other experts. The characteristics of a T-shape person are almost impossible to acquire through traditional education because the knowledge gained in this way is not sufficient for performing the job in today's circumstances, which is why additional education of employees, as systematic acquisition and development of knowledge, skills and abilities, is becoming increasingly important (Latham, 1988).

\section{Formalization methods of interorganizational relations in PPP: concession agreement and PPP agreement}

Formalization reflects the degree to which the behaviour of the organization members is based on rules, regulations and procedures, i.e., it reflects the extent to which this behaviour is standardized (Jones, 2012). The formalization of behaviour may be done by job, work flow and rules and its main goal is to regulate the behaviour of employees (Mintzberg, 1979). It becomes more relevant when the relationship involves numerous partners whose behaviour needs to be directed towards the objectives realization, and when one needs to make sure not to hamper a positive initiative, creativity and useful ideas. In a PPP, particular care should be taken to regulate the partnership in accordance with the contractual obligations and legislation, so as to avoid potential problems arising from different system values of the partners. The private partner is motivated by profit maximization, whereas the public partner is focused on providing a service at a satisfactory level and achieving the greatest value for money.

The foundation of the PPP is the relevant PPP legislation, national sector strategy and supporting legislation (Osborne, 2000). These documents define the types of services and expected results, identify the relevant public institutions and their roles, expertise and resources available to the public sector, the necessary processes and mechanisms of monitoring and control to achieve the planned results. For a country it is important to have an established central PPP unit, whose task is to oversee and channel the realization of projects of this kind. This unit has the task to coordinate the different public institutions involved in the procurement process and the implementation of PPP projects.

The first comprehensive law on PPP in Serbia, the "Law on Public-Private Partnership and Concessions" (Official Gazette of RS, no. 88/2011), was adopted in 2011 with the aim to create a suitable legal framework for the promotion and implementation of projects funded by the private sector in the field of infrastructure and public services. The Law on PPP with the recently adopted changes and amendments to the "Law on Communal Services" (Official Gazette of RS, no. 88/2011) and the "Law on Public Procurement" (Official Gazette of RS, no. 116/2008), constitute the core of the legal system for the implementation of PPP projects in Serbia. In addition to the Law of 2012, a Commission for PPP has been constituted as a central government organization in charge of the PPP (EPEC, 2014).

Pursuant to the Law on PPP in Serbia, the compensation to the private partner stipulated in the agreement can be paid by the state or the beneficiary. The duration of the agreement can be between 5 and 50 years, while the PPP may take the form of a concession or consortium (the so-called institutional PPP). The concession is defined as the right of the private partner to use a natural or public resource, or to organize activities of public importance and in turn receive a concession fee - paid by the state or beneficiary ${ }^{3}$. The private partner bears the commercial risk of exploitation of the commodity subject to concession. Within the consortium (or institutional PPP), the public partner buys shares or participates in the ownership of the company in charge of project implementation (EPEC, 2014).

In the PPP, there are a number of different contracts that regulate and formalize the behaviour of PPP participants: concession agreement, direct agreements, shareholders' agreement, credit facility agreements, design and build contract, operation and maintenance contract, etc. A key element of the legal structure of 
every PPP is the project or the concession agreement. This agreement stipulates the rights and obligations of the public and private partners, specifications and results the private partner is to deliver in the concession period, as well as the risk allocation. Precisely the risk allocation agreed in the concession agreement is the most important link in the PPP realization, since it is the basis for preparing the sub-contracts such as design and construction contract and the operation and maintenance contract. Most of the risks taken by the special purpose company (SPC) in the concession agreement are transferred to the constructors and operators through the above mentioned contracts, to the greatest extent possible. The goal of efficient risk allocation is to minimize risks borne by the SPC itself, and transfer as much risk as possible to the public partner, on the one hand, and the private sector, on the other, because such a cascade risk allocation is one of the basic conditions of project bankability. Countries like Great Britain and France, based on their longstanding practical experience, have developed models of PPP agreements that give a detailed and standardized definition of risk allocation among the partners. Exactly this is the specificity of PPP, because through numerous agreements many decisions have to be based on the principles and provisions agreed in those agreements, starting from the Project Agreement or the Concession Contract. Thus in England there is a so-called SoPC4 (Standardization of Project Finance Initiative Contracts version 4), in Scotland there is the NPD (Non-profit Distribution) model, and in France there is the Partnership Agreement ${ }^{4}$. In Serbia there is still no such a model, nor any indications for its development.

At first glance, one might be under the impression that in the interorganizational relations within the PPP the decision making process is decentralized to the participants that in a given project stage have the most important role. However, a more detailed analysis leads to the conclusion that most of the decisions are determined in advance by the contractual framework to which all participants must adhere. Potential problems arise in situations when participants do not obey the defined procedures and rules, which is one of the causes for failure and termination of PPP contracts. This is the reason why the organization and management of the PPP have to be thought of well in advance and properly arranged. Successful organization of the PPP should reconcile the principles of stability and flexibility, and provide PPP managers with manoeuvring space to make necessary interventions as they go along.

Conslusion

Interorganizational design and PPPs have become a very current topic in both theory and practice. The phenomenon of PPP has mainly been addressed from the perspective of legislation and generally recognized by classical macroeconomic paradigm. The paper tried to open a new perspective of dealing with this subject, from both organisational and managerial aspects. In this sense, the paper stresses the significance of organizational design of the PPP and SPC, which is in charge of implementing the project, so that the project in question has a solid support. The experience has shown that without strong organization, defined rules and principles, there is no successful project. This is why interorganizational relations involve a well-designed organizational structure focused on PPP objectives, and then appropriate organizational architecture, which clearly determines who should do what, how and by when. This is accomplished by establishing the special purpose companies (SPC), as well as through formal and legal organizational instruments such as the PPP agreements. In this paper affirmed are the benefits of the PPP and the significance and role of organizational support. The focus is on the knowledge transfer and learning, but also on the introduction of a managerial position from both private and public sector point of view - PPP manager, who needs to be a specialist in leading the PPP, apart from possessing general managerial skills. In Serbia, where capital, technologies and knowledge are scarce resources (Petković, Aleksić-Mirić, \& Stojković, 2014), the PPP model is more than welcome. The paper emphasizes the need for a more comprehensive understanding of the benefits of the PPP. Implementation of the project involves people who need to master the know-how to ensure that the results should be collected in the long run. Good contractual framework is important in that sense, but not sufficient, nor a guarantee for a successful project implementation. The organization of the PPP, which primarily includes people, is a good guarantee for collecting the benefits from PPP in the long run, especially for the beneficiary country. 


\section{REFERENCES}

[1] Alvesson, M., \& Thompson, P. (2005). Post-bureaucracy? In S. Ackroyd, R. Batt, P. Thompson, \& P. Tolbert, The Oxford Handbook of Work and Organization. Oxford: Oxford University Press, pp. 485-507.

[2] Burton, R., \& Obel, B. (2004). Strategic Organizational Diagnosis and Design: The Dynamics of Fit: Springer.

[3] Chandler, A. (1962). Strategy and Structure, Chapters in the History of the Industrial Enterprise. Cambridge: MIT Press.

[4] Dejvi, K. (2010). Predgovor u: Partnerstvo javnog i privatnog sektora: dobra i loša iksustva u odabranim zemljama u tranziciji. In D. Damjanović, Pavlović Križanić, T., Peteri, G. (Ed.). Beograd: Palgo centar.

[5] Delgado, M., Porter, M., \& Scott, S. (2010). Clusters and Enterpreneurship. Journal of Economic Geography, 10(4), 495-518.

[6] EPEC European PPP Expertise Centre. (2014b). Serbia: PPP Units and Related Institutional Framework. Luxembourg: European Investmen Bank

[7] Fjeldstad, D., Snow, C., Miles, R., \& Lettl, C. (2012). The Architecture of Collaboration. Strategic Management Journal(33), 734-750.

[8] Galbraith, J. (2014). Designing Organizations: Strategy, Structure, and Process at the Business Unit and Enterprise Levels. San Francisco: Jossey-Bass.

[9] Grandori, A. (2002). Organization and Economic Behavior. London and New York: Routledge.

[10] Gulati, R., Phanish, P., \& Tushman, M. (2012). Meta-organization design: rethinking design in interorganizational and community contexts. Strategic Management Journal, 33(6), 571-586.

[11] Handy, C. (1990). The Age of Unreason. Boston, MA: Harvard Business School Press.

[12] Higgins, K. L., \& Maciariello, J. A. (2004). Leading complex Collaboration in Network Organizations: A Multidisciplinary Approach. In M. Beyerlein, D. Johnson \& S. Beyerlein (Eds.), Building the Capabilities for Working across Boundaries (Vol. 10): Elsevier, pp. 203-241.

[13] Ho, P. H. K. (2006). Development of Public-Private Partnerships (PPPs) in China. Surveyours Times, 15(10).

[14] Holland, R. C. (1984). The new era in public-private partnerships. In R. P. Porter, Sweet, D. C. (Ed.), Rebuilding America Cities: Roads to Recovery. New Brunseick: Center for Urban Policy Research.

[15] Innovative Program Delivery (2012) Establishing a Public-Private Partnership Program: A example, P3 Toolkit.

[16] Jamali, D. (2004). Success and Failure Mechanisms of Public Private Partnerships (PPPs) in Developing Countries: Insights from Lebanese Context. The International Journal of Public Sector Management, 17(5), 503-519.

[17] Jaško, O., Jaško, A., \& Čudanov, M. (2010). Impact of management upon organizational network effectiveness. Management, 16(56), 5-13.

[18] Jones, G. (2012). Organization Theory, Design, and Change: Prentice Hall.

[19] Kates, A., \& Galbraith, J. (2007). Designing your organization using the Star model to solve 5 critical design challenges. San Francisco: Jossey-Bass.

[20] Latham, G. (1988). Human Resource Training and Development. Annual Review of Psychology, 39, 545-582.

[21] Mijatovic, I. (2014). The Need for Standardization in SMEs Networks. Management, 73, 35-40.

[22] Miles, R.E., \& Snow, C.C. (1992). Causes of Failure in Network Organizations. California Management Review, 34(4), 53-72.

[23] Mintzberg, H. (1979). The Structuring of Organizations, a synthesis of the research. New Jersey: Prentice Hall.

[24] Mintzberg, H. (1980). Structure in 5's: a synthesis of the research on organization design. Management Science, 26(3), 322-341.

[25] O'Callaghan, R. (2005). Technological Innovation in Organizations and Their Ecosystems in Infrastructure Development. In W. H. Dutton, Kahin, B., O'Callaghan, R., Wyckoff, A. W. (Ed.), Transforming Enterprise, The Economic and Social Implications of Information Technology. London: The MIT Press, pp. 1-12.

[26] Osborn, R. N., \& Baughn, C. C. (1990). Forms of interorganizational governance for multinational alliances. Academy of Management Journal, 33, 503-519.

[27] Osborne, S. (2000). Public-private partnerships, theory and practice in international perspective. London and New York: Routledge.

[28] Petković, M., \& Lazarević, S. (2012). Managing Interorganizational Relations: Design of Shared Services Centre. Management, 64, 55-67. 
[29] Petković, M., Aleksić-Mirić, A., \& Stojković, D. (2014). The Role of Government in Creating Strategic Partnerships in Serbia: Lessons Learnt? in B. Cerović (Ed.), The Role of the State in the New Growth Model of the Serbian Economy, Beograd: Ekonomski fakultet, pp. 281-301.

[30] Petković, M., Aleksić-Mirić, A., \& Čudanov, M. (2014). Designing a Learning Network Organization. Management, 73, 17-24.

[31] Rainey, H. G., \& Bozeman, B. (2000). Comparing Public and Private Organizations: Empirical Research and the Power of the A Priori. Journal of Public Administration Reseacrh and Theory, 10(2), 447-470.

[32] Robinson, H., Carrillo, P., Anumba C. J., \& Patel, M. (2010). Governance \& Knowledge Management for Public-Private Partnerships. Chichester: Wiley-Blackwell.

[33] Roseneau, P. W. (1999). The Strengths and Weaknesses of Public Private Policy Partnerships. American Behavioral Scientist, 43(1), 10-34.

[34] Smyth, H., \& Edkins, A. (2007). Relationship management in the management of PFI/PPP prjects in the UK. Science Direct, 25, 232-240.

[35] Snow, C.C., Miles, R.E., Coleman, H.J., \& Henry, J. (1992). Managing 21st Century Network Organizations. Organizational Dynamics, 20(3), 4-20.

[36] Stock, R. M. (2006). Interorganizational Teams as Boundary Spanners Between Suppliers and Customer Companies. Journal of Academy of Marketing Science, 34(4), 588-599.

[37] Van der Wal, Z., De Graaf, G., \& Lasthuizen, K. (2008). What's valued most? Similarities and differences between the organizational values of the public and private sector. Public Administration, 86(2), 465-482.

[38] Yang, Y., Hou, Y., \& Wang, Y. (2013). On the Development of Public-Private Partnerships in Transitional Economies: an Explanatory Framework. Public Administration Review, 73(2), 301-310.

[39] Yescombe, E. R. (2007). Public-Private Partnership, Principles of Policy \& Finance. London: Yescombe Consulting Ltd.

[40] Zaheer, A., McEvily, B., \& Perrone, V. (1998). Does trust matter? Exploring the effects of inter-organizational and interpersonal trust on performance. Organization Science, 9, 141-159.

[41] Zammuto, R., Griffith, T., Majchrzak, A., Dougherty, D., \& Faraj, S. (2007). Information Technology and the Changing Fabric of Organization. Organization Science, 18(5), 749-762.

[42] Zhang, X. (2005). Critical Success Factors for Public-Private Partnerships in Infrastructure Development. Journal of Construction Engineering and Management, 131(1), 3-14.

[43] Zhang, Z., \& Jia, M. (2009). When Does Trust Influence Cooperation Effects in Public-Private Partnerships? SAM Advanced Management Journal, 21-32.

Receieved: October 2015. Accepted: December 2015.

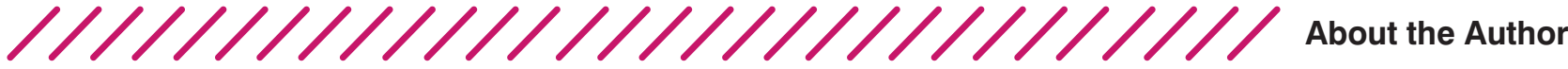

\section{Mirjana Petković \\ University of Belgrade, Faculty of Economics, Serbia mirjana.ekof@beotel.net}

Mirjana Petković, Ph.D., is a professor at the University of Belgrade, Faculty of Economics, where she is a lecturer in the following courses: Enterprise Organization, Organizational Design, Organizational Behaviour and Human Resource Management.

She is the author of the book Organizational Behaviour with Human Resource

Management and the author and co-author of several monographs and numerous articles in the fields of organizational theory, organizational structure, organizational behaviour, organizational design, culture and changes. Professor Petković has also taken part in many projects as a consultant or project manager.

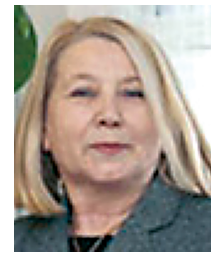


Dubravka Djedović-Nègre European Investment Bank (EIB)

djedovic@eib.org

Dubravka Djedović-Nčgre is in charge in the EIB of financing Public-Private Partnerships (PPPs) and Project Finance initiatives in Benelux, France, Ireland and UK mostly in transport, energy, health and education sectors. Prior to that, Dubravka was in charge of financing infrastructure projects in the Western Balkans, including Serbia. She won the

Project Finance and EMEA Finance Magazine Deal of the Year in 2013 for financing Zagreb Airport Concession project in Croatia, the first ever PPP for the EIB to reach the financial close in the Balkans. She holds a masters degree from the SDA Bocconi in Milan, Italy (2004) and a bachelor degree of the Faculty of Economics, University of Belgrade (2002).

Jelena Lukić,

Parallel d.o.o.

jelena.jl.lukic@gmail.com

Jelena Lukić received a bachelor (2011) and a masters (2012) degrees from the Faculty of Economics, University of Belgrade. Currently she is a PhD student in Business Management with a special interest in big data technologies and organizational design. She is the author or co-author of several research papers in the field of information and communication technologies and organizational design
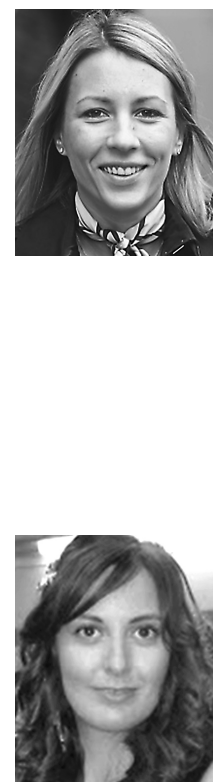